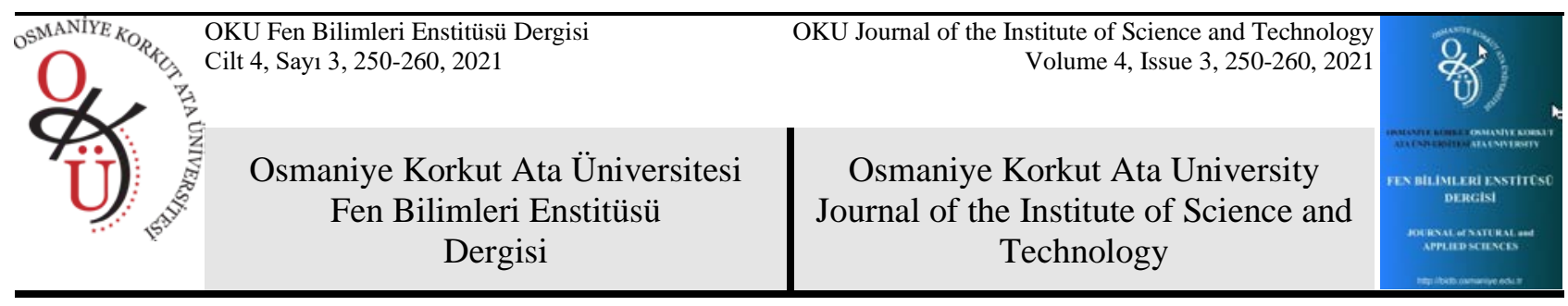

\title{
Organic Food Nutrition Knowledge Level of Olympic Boxers in Turkey
}

\author{
Murat KUL ${ }^{1}$, Betül GIDIK ${ }^{2}$, Osman GIDIK ${ }^{3 *}$, Onur ŞiPAL ${ }^{4}$, Önder ŞiPAL ${ }^{5}$ \\ ${ }^{1}$ Bayburt University, School of Physical Education and Sports, Department of Sports Management, 69000 Bayburt, Turkey \\ ${ }^{2}$ Bayburt University, Faculty of Applied Science, Department of Organic Farming Management, 69000 Bayburt, Turkey \\ ${ }^{3}$ Bayburt University, Graduate Education Institute, Department of Physical Education and Sports, 69000 Bayburt, Turkey \\ ${ }^{4}$ Bayburt University, Technical Sciences Vocational School, Department of Property Protection and Security \\ ${ }^{5}$ Bayburt University, Graduate Education Institute, Department of Physical Education and Sports, 69000 Bayburt, Turkey
}

${ }^{1}$ https://orcid.org/0000-0001-6391-8079

${ }^{2}$ https://orcid.org/0000-0002-3617-899X

${ }^{3}$ https://orcid.org/0000-0003-0811-9324

${ }^{4}$ https://orcid.org/0000-0002-4064-6813

${ }^{5}$ https://orcid.org/0000-0001-6018-548X

* Corresponding author: osmangidik@gmail.com

\section{Research Article}

\section{Article History:}

Received: 02.05.2021

Accepted: 08.07.2021

Published online: 15.12 .2021

\section{Keywords:}

Sportman nutrition

Organic food

Organic nutrition

National boxer

\begin{abstract}
One of the most important features of organic foods is that they are produced by organic farming methods, which is an environmentally friendly form of agricultural production. This study aims to determine the organic food awareness level and the perception of disadvantage towards organic food of all Olympic boxers in Turkey and attitudes towards organic food. The sample of the study consists of 29 volunteer athletes, 19 men, and 10 women, Olympic boxers in Turkey. It was ensured that the participants answered the demographic and scale questions in the survey via the internet. In the statistical evaluation of the data obtained from this study, the statistical software of SPSS 26.0 version; Cronbach's Alpha reliability, KruskalWallis $\mathrm{H}$ and Mann Whitney $\mathrm{U}$ tests were applied. In conclusion, a significant difference was determined between the organic food awareness level and attitudes towards organic foods and the national class variable at the level of $\mathrm{P}<0.05$.
\end{abstract}

\section{Türkiye'deki Olimpik Boksörlerin Organik Gıdalarla Beslenme Bilgi Düzeyi}

\section{Araştırma Makalesi}

Makale Tarihçesi:

Geliş tarihi: 02.05.2021

Kabul tarihi: 08.07.2021

Online Yayınlanma: 15.12.2021

\section{Anahtar Kelimeler:}

Sporcu beslenmesi

Organik gida

Organik beslenme

Milli boksör

\section{ÖZET}

Organik gıdaların en önemli özelliklerinden biri, tarımsal üretimin çevreye duyarlı bir şekli olan organik tarım yöntemleriyle üretilmeleridir. Bu çalışma, Türkiye'deki tüm Olimpik boksörlerin organik gıda bilinç düzeyini ve organik gıdaya yönelik dezavantaj algısını ve organik gıdaya yönelik tutumlarını belirlemeyi amaçlamaktadır. Araştırmanın örneklemini Türkiye'deki 29 gönüllü sporcu, 19'u erkek ve 10'u kadın Olimpik boksör oluşturmaktadır. Katılımcıların ankette yer alan demografik ve ölçek sorularını internet üzerinden yanıtlamaları sağlanmıştır. Bu çalışmadan elde edilen verilerin istatistiksel değerlendirmesinde SPSS 26.0 versiyonunun istatistiksel yazılımı; Cronbach's Alpha güvenirliği, Kruskal-Wallis H ve Mann Whitney U testleri uygulanmıştır. Sonuç olarak, organik gıda farkındalık düzeyi ve organik gıdalara yönelik tutum ile millilik sınıf değişkeni arasında $\mathrm{P}<0,05$ düzeyinde anlamlı bir fark tespit edilmiştir.

To Cite: Kul M., Gıdık B., Gıdık O., Şipal O., Şipal Ö. Organic Food Nutrition Knowledge Level of Olympic Boxers in Turkey. Osmaniye Korkut Ata Üniversitesi Fen Bilimleri Enstitüsü Dergisi 2021; 4(3): 250-260.

\section{Introduction}

Nowadays, sports an integral part of life and one of the important factors in the happiness of individuals (Yalcinkaya, 1993) and it is defined as a science that enables the communication between the elements 
contributing to physical and cognitive development. Besides, sports activities that should be carried out in the light of scientific knowledge cannot go beyond playing games when they occur as recreational activities (DPT, 1972). Today, all professional and amateur teams warm up with recreational games before the competition in all branches. It is seen in studies that recreational games have an effect on achieving goals. Athletes who want to succeed in this direction can achieve these goals only by applying certain training and nutrition techniques (Karakucuk, 1989).

Choosing an adequate and balanced diet method is of great importance for elements such as performance improvement, recovery, and disability protection (Aoi, 2006; Niess, 2007). An adequate and balanced intake of nutrients needed by the body is defined as proper nutrition. It is also known that proper nutrition is directly related to variables such as age and gender, as well as being defined as the amount, quality, balanced and adequate supply of energy needs (Baysal, 2012; Arikan, 2015; Dulger, 2015).

As a result of the inability of athletes to meet the energy they need or to make the right food choices and an inadequate or unbalanced nutritional situation arises. In addition to the fact that athletes face various problems, this leads to a negative impact on their mental and physical development. All this suggests that the choice of nutrition method with athlete health will be directly proportional (Baysal, 2012; Karaagaoglu, 2015). Energy requirements of athletes may increase 2-3 times compared to sedentary individuals depending on elements such as sports branch, training time. Variables such as sports, intensity and duration of exercise also cause nutrition methods to differ.

In addition to various sports, boxing is also held in the weight competitions determined by sports federations. Boxers, as in other weight sports, usually prefer to compete in a category that is below the current weight. Because of all this, boxers need to constantly keep their weight under control. In studies, it has been determined that excessive and rapid weight loss negatively affects the health and performance of athletes. In this direction, the training, competition, and nutrition programs of boxers who want to succeed should be carefully established and athletes should comply with the program (Zengin, 2003). Besides, it is believed that boxers who are aware of the athlete's health, healthy life, and the environment will prefer organic foods in nutrition.

The most important feature of organic foods; they do not harm the environment, healthy and high-quality production with organic farming methods are used where controlling all stages of production certified and controlled by third parties and is produced without chemical input (Ertan, 2005, Tandona, 2020). Organic foods are produced in a way that is intended for needs, does not harm human health, and using sustainable methods (Gunduz, 2007). The basic method of nutrition in which the foods obtained as a result of these applications are used is called organic nutrition. It is known that the origin of biodynamic agriculture, which was first raised in 1924 and which is easily adapted to organic-biological or environmental conditions, dates back to the last centuries (Anonymous, 2017).

Uses and benefits of organic foods considering the role of nutrition in this and the performances of athletes; boxers' sporting success and a healthy life with the idea that there may be a connection between the choice of organic foods has emerged. This study aims to determine the organic food awareness level and the perception of disadvantage towards organic food and their attitude towards organic food. Besides, it is believed that the 
study will contribute to the literature as a new source since similar studies have not been found before and the entire universe has participated in the evaluation.

\section{Material and Methods}

\section{Research group}

The working group consists of 29 people in total. 19 male and 10 female athletes, who were in the Olympic boxing team in 2020, who will participate in the Olympics and who are candidates to participate, participated in the study voluntarily. The research group covers all Olympic boxers in Turkey. In this study, the convenience sampling method was preferred because volunteer athletes were included in the study (Coskun, 2017).

With the help of the "A field study on factors and attitudes affecting organic product consumption" (Sarikaya, 2007), "The perception of organic products by FEAS academic and administrative staff and FEAS formal and evening education students of Erciyes University” (Kacur, 2009), studies, the scale of the study were created. The result of the organic foods awareness level perception reliability test (Cronbach's Alpha) was determined as 0.912 , the result of the disadvantage perception scale of the organic food reliability test was determined as 0.733 , and the result of the attitude scale of the organic food reliability test was determined as 0.755 . When creating surveys, these high-reliability scales were used as 5 points Likert scale after some minor revisions compared to the participants.

\section{Data collection}

The Olympic boxers who participated in the study were explained about the purpose, importance and method of the research. It was ensured that the participants answered the demographic and scale questions in the survey via the internet. They were informed that all the data obtained would be used only for the research and that the names of the boxers would not be included in the study. It was conducted in accordance with the Helsinki Declaration and by obtaining a signed consent form from the participants.

\section{Data analysis}

The result of the study was statistically evaluated by applying, Cronbach's Alpha reliability test, KruskalWallis $\mathrm{H}$ test and Mann Whitney U test, by using SPSS 26.0 version statistical program in the analysis of the data. Non-parametric tests were used because the number of participants was less than 30.

\section{Ethics approval and consent to participate}

The study protocol was reviewed and approved by the Bayburt University Ethics Committee (2020/87) (16.10.2020).

\section{Results}

Cronbach's Alpha reliability test result (Table 1.) in this study was determined that the organic foods awareness level perception scale is in the range of high reliability, the disadvantage perception scale of organic food is in 
the range of high reliability, and the attitude scale of organic food is in the range of low reliability. Besides, the common Cronbach's Alpha reliability test result of all these scales was found to be in a fairly reliable range (Yildiz, 2018). The results showed that the questions used were reliable.

Table 1. Cronbach's Alpha reliability test

\begin{tabular}{lcc}
\hline \multicolumn{1}{c}{ Reliability Statistics } & & \\
\hline Scales & Cronbach's Alpha & N of Items \\
\hline Organic foods awareness level perception scale & 0.853 & 14 \\
Disadvantage perception scale of organic food & 0.639 & 6 \\
Attitude scale of organic food & 0.504 & 4 \\
General reliability of the scale & 0.773 & 24 \\
\hline
\end{tabular}

A total of 29 participants, 19 male and 10 female athletes, who are part of the Olympic boxing team and who are candidates or will be candidates to participate in the Olympics, were included in this study. The demographic data of the participants in the study are shown in Figure 1.

The ages of the participants in this study ranged from 17 to 38, (Table 2.) but the sports ages ranged from 6 to 23. There were no significant differences at the level of $\mathrm{P}<0.05$ between the organic foods awareness level perception, disadvantage perception of organic food and attitude towards organic food and these variables as a result of Kruskal-Wallis H Test.

The education status of the Olympic boxers in Turkey is listed as high school, undergraduate and graduate. The Kruskal-Wallis H test was performed to determine the differences between this variable and the organic food awareness level perception, the disadvantage perception of organic food, and the attitude towards organic food (Table 3.). According to the test result, there was no significant difference at the level of $\mathrm{P}<0.05$.

Olympic boxers in Turkey stated that they worked with their, current coaches for 3-23 years; the number of becoming national athletes ranged from 3 to 117. According to the Kruskal-Wallis h test, which was conducted to determine the differentiation between these variables and organic food awareness level perception, disadvantage perception of organic food and attitude towards organic food, it was determined that there were no significant differences at the level of $\mathrm{P}<0.05$.

According to the place of residence, educational status of parents, monthly income of the family, whether there is a licensed boxer in the family or not variables of the Olympic boxers in Turkey, as a result of the KruskalWallis $\mathrm{H}$ test to determine the differences between the level of organic food awareness level perception, disadvantage perception of organic food and attitude towards organic food, there was no significant difference at the level of $\mathrm{P}<0.05$. 
Table 2. The Kruskal-Wallis H test for ages of participants

\begin{tabular}{|c|c|c|c|c|c|}
\hline \multirow{12}{*}{ 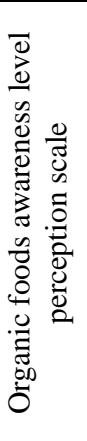 } & Age & $\mathbf{N}$ & Mean Rank & Test Statistics & Organic foods awareness level perception scale \\
\hline & 17.00 & 1 & 18.50 & Kruskal-Wallis $\mathrm{H}$ & 6.340 \\
\hline & 19.00 & 6 & 18.50 & df & 10 \\
\hline & 20.00 & 2 & 10.50 & $\mathrm{p}$ & 0.786 \\
\hline & 21.00 & 4 & 17.13 & & \\
\hline & 22.00 & 1 & 4.00 & & \\
\hline & 23.00 & 1 & 23.50 & & \\
\hline & 24.00 & 6 & 11.92 & & \\
\hline & 25.00 & 1 & 21.00 & & \\
\hline & 26.00 & 5 & 13.00 & & \\
\hline & 31.00 & 1 & 17.00 & & \\
\hline & 38.00 & 1 & 14.00 & & \\
\hline \multirow{12}{*}{ 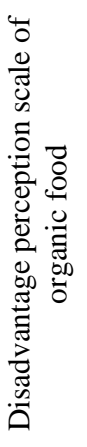 } & Age & $\mathbf{N}$ & Mean Rank & Test Statistics & Disadvantage perception scale of organic food \\
\hline & 17.00 & 1 & 20.00 & Kruskal-Wallis H & 16.371 \\
\hline & 19.00 & 6 & 16.58 & df & 10 \\
\hline & 20.00 & 2 & 7.00 & $\mathrm{p}$ & 0.089 \\
\hline & 21.00 & 4 & 5.25 & & \\
\hline & 22.00 & 1 & 25.50 & & \\
\hline & 23.00 & 1 & 3.00 & & \\
\hline & 24.00 & 6 & 17.00 & & \\
\hline & 25.00 & 1 & 20.00 & & \\
\hline & 26.00 & 5 & 21.80 & & \\
\hline & 31.00 & 1 & 7.00 & & \\
\hline & 38.00 & 1 & 14.00 & & \\
\hline \multirow{12}{*}{ 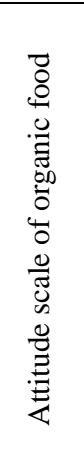 } & Age & $\mathbf{N}$ & Mean Rank & Test Statistics & Attitude scale of organic food \\
\hline & 17.00 & 1 & 29.00 & Kruskal-Wallis H & 9.414 \\
\hline & 19.00 & 6 & 17.67 & df & 10 \\
\hline & 20.00 & 2 & 13.00 & $\mathrm{p}$ & 0.493 \\
\hline & 21.00 & 4 & 15.50 & & \\
\hline & 22.00 & 1 & 13.00 & & \\
\hline & 23.00 & 1 & 21.50 & & \\
\hline & 24.00 & 6 & 12.00 & & \\
\hline & 25.00 & 1 & 24.00 & & \\
\hline & 26.00 & 5 & 13.00 & & \\
\hline & 31.00 & 1 & 3.50 & & \\
\hline & 38.00 & 1 & 13.00 & & \\
\hline
\end{tabular}

$\mathbf{N}$ : Number of participants

Table 3. The Kruskal-Wallis $H$ test for education status of participants

\begin{tabular}{|c|c|c|c|c|c|}
\hline \multirow{4}{*}{$\begin{array}{l}\text { Organic foods } \\
\text { awareness } \\
\text { level } \\
\text { perception } \\
\text { scale }\end{array}$} & Education Status & $\mathbf{N}$ & Mean Rank & Test Statistics & $\begin{array}{l}\text { Organic foods awareness level perception } \\
\text { scale }\end{array}$ \\
\hline & High school & 12 & 17.50 & Kruskal-Wallis H & 1.789 \\
\hline & Undergraduate & 16 & 13.19 & df & 2 \\
\hline & Graduate & 1 & 14.00 & $\mathrm{p}$ & 0.409 \\
\hline \multirow{4}{*}{$\begin{array}{l}\text { Disadvantage } \\
\text { perception } \\
\text { scale of } \\
\text { organic food }\end{array}$} & Education Status & $\mathbf{N}$ & Mean Rank & Test Statistics & $\begin{array}{l}\text { Disadvantage perception scale of organic } \\
\text { food }\end{array}$ \\
\hline & High school & 12 & 16.08 & Kruskal-Wallis H & 0.344 \\
\hline & Undergraduate & 16 & 14.25 & df & 2 \\
\hline & Graduate & 1 & 14.00 & $\mathrm{p}$ & 0.842 \\
\hline \multirow{4}{*}{$\begin{array}{l}\text { Attitude scale } \\
\text { of organic } \\
\text { food }\end{array}$} & Education Status & $\mathbf{N}$ & Mean Rank & Test Statistics & Attitude scale of organic food \\
\hline & High school & 12 & 17.71 & Kruskal-Wallis H & 2.416 \\
\hline & Undergraduate & 16 & 13.09 & df & 2 \\
\hline & Graduate & 1 & 13.00 & $\mathrm{p}$ & 0.299 \\
\hline
\end{tabular}

N: Number of participants 


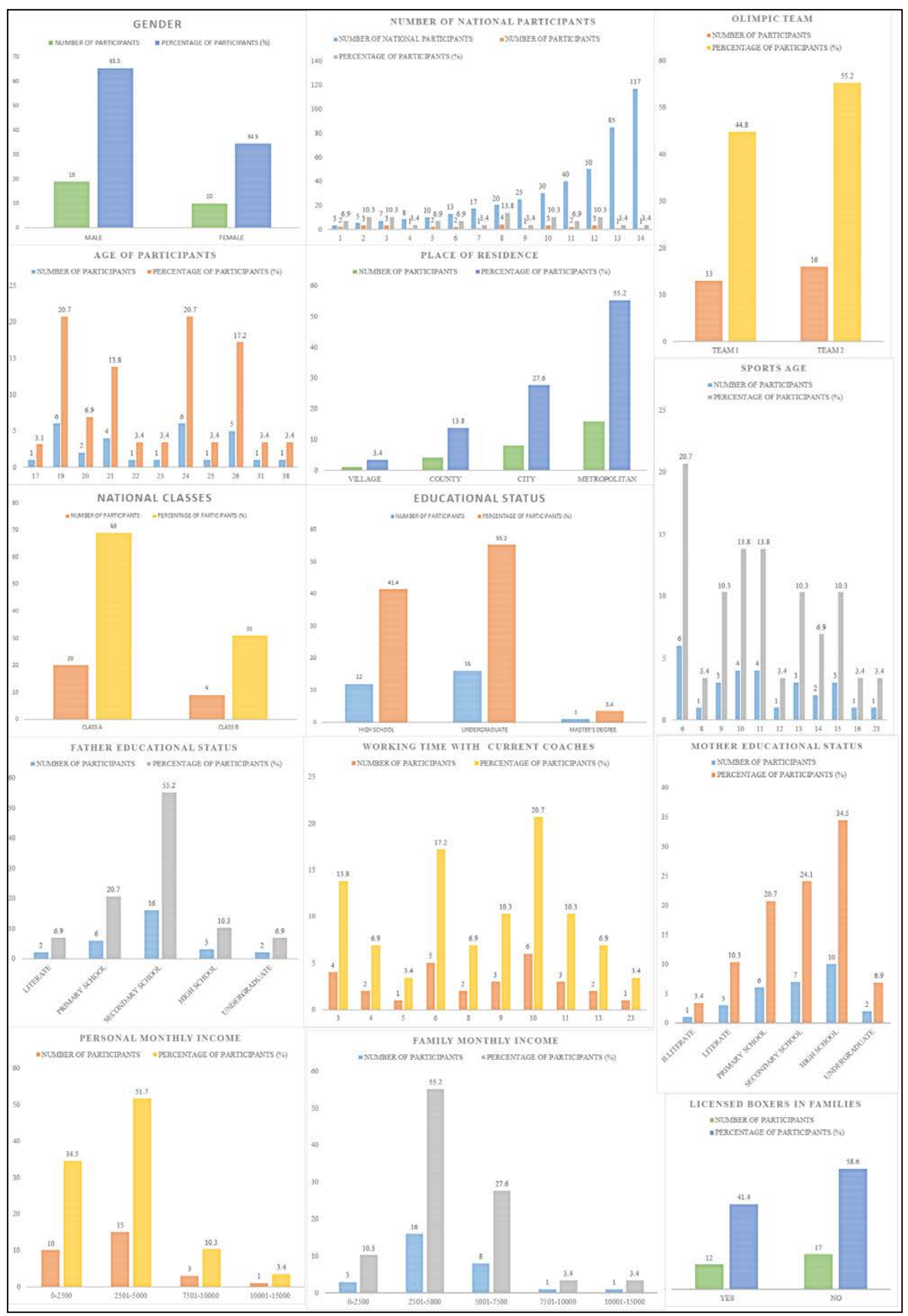

Figure 1. The demographic data of the participants 
All Olympic boxers in Turkey, 19 men, and 10 women, 29 people in total participated in this study. To determine the differences between organic food awareness level perception, disadvantage perception of organic food and attitude towards organic food, according to gender variables, Mann Whitney U test determined that there were no significant differences at the level of $\mathrm{P}<0.05$ and that the organic food preferences of both groups were similar to each other. National boxers in Turkey have stated that they are in the first and second teams in the Olympic squad. According to this variable, the Mann-Whitney U test was performed to determine the differences between organic foods awareness level perception, disadvantage perception of organic food, and attitude towards organic food, and it was determined that there were no significant differences at the level of $\mathrm{P}<0.05$.

20 of the Olympic boxers in Turkey who participated in this study reported that they took part in Class A and 9 in Class B. By conducting the Mann Whitney U test to determine the differences between the national class variable of participants and the organic food awareness level perception, the disadvantage perception of organic food, and the attitude towards organic food; (Table 4.) it was determined that there were significant differences at the level of $\mathrm{P}<0.05$ between the perception of organic foods awareness and the attitude towards organic food and the national class variable, as well as no significant differences between the perception of disadvantage towards organic food and the national class variable.

Table 4. Mann Whitney U Test results according to the nationality class variable of Olympic boxers

\begin{tabular}{|c|c|c|c|c|c|c|c|}
\hline & $\begin{array}{l}\text { National } \\
\text { class }\end{array}$ & $\mathbf{N}$ & Mean Rank & Sum of & $\begin{array}{c}\text { Mann } \\
\text { Whitney U }\end{array}$ & $\mathbf{U}$ & $\mathbf{p}$ \\
\hline \multirow{2}{*}{$\begin{array}{l}\text { Organic foods awareness } \\
\text { level perception scale }\end{array}$} & A & 20 & 12.90 & 258.00 & \multirow{2}{*}{48.000} & \multirow{2}{*}{-1.989} & \multirow{2}{*}{0.047} \\
\hline & B & 9 & 19.67 & 177.00 & & & \\
\hline \multirow{2}{*}{$\begin{array}{l}\text { Disadvantage perception } \\
\text { scale of organic food }\end{array}$} & A & 20 & 15.35 & 307.00 & \multirow{2}{*}{83.000} & \multirow{2}{*}{-.336} & \multirow{2}{*}{0.737} \\
\hline & B & 9 & 14.22 & 128.00 & & & \\
\hline \multirow{2}{*}{$\begin{array}{l}\text { Attitude scale of organic } \\
\text { food }\end{array}$} & $\mathbf{A}$ & 20 & 13.00 & 260.00 & \multirow{2}{*}{50.000} & \multirow{2}{*}{-2.036} & \multirow{2}{*}{0.042} \\
\hline & B & 9 & 19.44 & 175.00 & & & \\
\hline
\end{tabular}

N: Number of participants *Significant at $\mathrm{p}<0.05$ level

\section{Discussion}

This study was conducted to determine the impact of demographic differences of all Olympic boxers in Turkey on organic food preferences. In this context, athletes who make up the entire universe participated in the study and answered questions about the organic food awareness level perception, the disadvantage perception of organic food and the attitude towards organic food.

The results of the study were evaluated and showed that the age of the participants did not cause any changes in attitudes or perceptions about organic foods. Acar (2008), obtained parallel results with our study on the determination of nutritional information and habits of boxers and reported that the age variable does not affect eating habits. Cupisti (2002), reported significant differences between the age variable and the level of nutritional information in their study, revealing different results than this study. Again Kacur (2008) and İnal et al. (2008), reported that the age variable was effective in organic food preferences and obtained different results in their studies. It has led to the idea that these resulting differences may be related to the selfsufficiency, knowledge levels, quality of life and preferences of the sample group. 
It was determined that the different educational status of Olympic boxers also did not affect their preference for organic food, Sayin et al. (2005), reported that educational status is an important variable in organic food consumption preferences in his studies and that there are significant differences between educational status and organic food preferences. In the different results obtained in these studies, it is thought that the quality or field differences of the education obtained are effective.

This result is supported by a similar study conducted earlier Acar (2008), which was obtained by determining that the sports age variable of participants did not affect organic food preferences. Studies on this subject show that Olympic boxers have common judgments about nutrition, or that those with fewer sports age take examples of boxers with higher sports age in terms of their eating habits. Besides, although the number of national participants and their working time with their current coaches were different, these variables were not effective in organic food preferences. This result showed that there is no differentiation between the coachathlete relationship and nutritional choices and that the number of becoming national athlete does not affect the perception and knowledge levels of organic food products.

Although situations of the Olympic boxers in Turkey such as residence, the educational status of parents, the monthly income of themselves and their family, and whether they have licensed boxers in their families differ, it was determined that these differences did not affect their organic food preferences. A study conducted earlier by Acar (2008), also obtained similar results according to the educational status of the parents and found no significant difference at the level of $\mathrm{P}<0.05$. İnal et al. (2005) and Sayin et al. (2005), reported that monthly income had an impact on attitudes and awareness levels towards organic foods. It is thought that the difference between these results may be due to some variables such as monthly income, as well as cultural differences and occupational differences.

The participants consist of 29 Olympic boxers, 10 women and 19 men. In this study, it was concluded that the gender variable was not effective in organic food preferences and perception levels. The results of some previous studies on this subject were examined and found to be parallel to the ones in this study (Corley et al., 1990; Ozcelik and Surucuoglu, 2000; Akil, 2004; Congar and Ozdemir, 2004; Acar, 2008). According to these data, the organic eating habits of Olympic boxers do not vary depending on gender and are universal.

It was determined that the organic food preferences of the participants in different teams in the Olympic squad in Turkey were similar to each other, and it was concluded that the team variable was not effective in organic nutrition preferences. In this case, it is thought that it may be effective for participants to go through the same processes and share the same environments regardless of the first or second team.

$69 \%$ of the national boxers who participated in this study reported that they were in Class A and 31\% were in Class B. Participants in different national classes showed significant differences in the level of awareness of organic food and attitude to organic food and national classes at the level of $\mathrm{P}<0.05$, while the perception of disadvantages to organic food did not change depending on the national class. Goktas (2010) and Koc (2014), in their studies on the eating habits of national athletes showed results supporting this study by stating that being a national athlete is related to eating habits. Despite this; Yarar et al. (2011), in their study, in which elite athletes determined their nutritional knowledge and habits, showed different results from this study, noting that there was no significant difference between the national class and the eating habit. Although this difference 
is believed to be caused by the sample group, it is also possible that nutritional choices between class A national boxers and class B national boxers may be a distinguishing factor.

\section{Conclusion}

As a result, it was determined that the level of organic foods awareness, the perception of disadvantage towards organic food and the attitude towards organic food of the Olympic boxers in Turkey who participated in this study did not differ much depending on their demographic characteristics. In particular, participants' age, gender, educational status, where they are in the Olympic squad in the team, the ages of the sport, working time with coaches, the number of being national athlete, place of residence, parents' educational status, having a licensed boxer in the family, personal and family income and knowledge of variables such as the choice of the organic foods showed an absence of significant differences between the levels of about this topic. Besides, it has been determined that there is a significant differentiation between the national athlete classes of Olympic boxers and the awareness levels of organic food and their attitude towards organic food. Considering the organic food knowledge level of the athletes, it is thought that it may be possible to create a different marketing and service area by producing new products specific to this area. It is believed that this study can be developed as a new source in the literature and provide insight into more comprehensive studies. In addition, according to the results obtained; it has been seen that boxers do not have enough knowledge about organic foods and the idea that more comprehensive trainings should be organized on this issue has emerged.

\section{Statement of Conflict of Interest}

Authors have declared no conflict of interest.

\section{Author's Contributions}

The contribution of the authors is equal.

\section{References}

Acar G. Determining the nutritional knowledge and habits of boxers. Master's Thesis, Selcuk University, Institute of Health Sciences, Konya, 2008.

Akil M. Determination and evaluation of nutritional awareness of athletes dealing with throwing branches of athletics. Master's Thesis, Selcuk University Institute of Health Sciences, Konya, 2004.

Anonymous. Organic farming in Germany. Federal Ministry of Food and Agriculture, 2017.

Aoi W., Nait Y., Yoshikawa T. Exercise and functional foods. Nutrition Journal 2006; 5(15): 1-5.

Arikan ZY. Nutrition habits of university students: Dumlupınar University Case. Institute of Science, Master Thesis, Dumlupınar University, Kutahya, 2015.

Baysal A. Nutrition. Ankara: Hatiboglu Publishing; pp.12-24; 2012.

Congar O., Ozdemir L. Knowledge levels of physical education teachers about general nutrition and sports nutrition in Sivas city center. C.U. Faculty of Medicine Journal 2004; 26: 123-118. 
Corley G., Demarest-Litcfort M., Bazzarre TL. Nutrition knowledge and dietary practices of college coaches. J Am Diet Assoc, 1990; 90: 705-709.

Coskun R., Altunisik R., Yildirim E. Research methods in social sciences SPSS applied. Sakarya: Sakarya Publishing, Updated 9th Edition; 2017.

Cupisti A., D'Alessandro C., Castrogiovanni S., Barale A., Morelli E. Nutrition knowledge and dietary composition in Italian adolescent female athletes and non-athletes. Int J Sport. Nutr Exerc Metab 2002; 12: 207-219.

Dulger H. Nutritional habits and obesity prevalence in Bartin University health services vocational school students. Health Sciences Institute, Master Thesis, Duzce University, Duzce, 2015.

DPT. Five-year development plan, youth and sports special expertise commission report. DPT. Ankara: Undersecretariat Publications; 1972.

Ertan S. Determination of health personnel's opinions on consumption of organic foods. Master Thesis, Gazi University Institute of Educational Sciences, Ankara, 2005.

Goktas Z. Nutritional habits of active national athletes and evaluation of contamination and positive doping risk in nutritional supplements used frequently. Master Thesis, Hacettepe University, Institute of Health Sciences, Ankara, 2010.

Gunduz Y., Kaya M. European Union agricultural policy and the possible impact on the development of organic agriculture in Turkey. Electronic Journal of Social Sciences; 2007; 6(21): 305-330.

Inal E., Akin M., Cicek R., Toksari M. A research to examine the relationship between consumers' beliefs on organic foods, demographic characteristics and individual values. 13. National Marketing Congress, Sustainability and Marketing Proceedings, 30 October-1 November, 2008, 195-213, Adana.

Kacur LL. Perception of organic products by academic and administrative staff of Erciyes University and faculty of business administration day and evening education. Erciyes University Faculty of Economics and Administrative Sciences Journal 2009; 33: 249-277.

Karaagaoglu N., Samur GE. Mother and child nutrition. Ankara: Pegem Academy Publications; 69; 2015.

Karakucuk S. Training of a physical education teacher. Ankara: Gazi University Publications; 24; 1989.

Koc M. Investigation of nutritional habits of wrestlers participating in national team development camps and their use of nutritional support products, Master Thesis, Kahramanmaras Sutcu Imam University, Institute of Health Sciences, Department of Physical Education and Sports, 2014.

Niess AM., Hipp A., Thoma S., Striegel H. Performance food in sports. Therapeutische Umschau 2007; 64(3): 181-185.

Ozcelik AO., Surucuoglu SMT. A study on the nutritional knowledge of medical doctors. Nutrition and Diy Derg, 2000; 29: 11-16.

Sarikaya N. A field study on factors and attitudes affecting organic product consumption. Kocaeli University Journal of Social Sciences Institute 2007; 2(14): 110-125. 
Sayin C., Mencet N., Ozkan B., Brumfield RG. The organic farming movement in Turkey. Hortechnology. 2005, October-December, 15(4): 1-8.

Tandona DA., Kaurd P., Kushwahf S., Salog J. Behavioral reasoning perspectives on organic food purchase. Appetite 2020; 154: 104786.

Yalcinkaya M., Saracaloglu A., Varol R. University students' views and expectations about sports. Journal of Sport Sciences 1993; 4: 2-13.

Yildiz D., Uzunsakal E. Comparison of reliability tests in field studies and an application on agricultural data. Journal of Applied Social Sciences 2018; 1(1): 14-28.

Yarar H., Gokdemir K., Eroglu H., Ozdemir G. Evaluation of the nutritional knowledge and habits of elite athletes. Selcuk University Journal of Physical Education and Sports Science 2011; 13(3): 368-371.

Zengin B., Yilmaz S., Gulmez I., Ramazanoglu N., Soykan A., Demir A. Investigation of the effects of fast weight loss on general strength in elite young female judoists. Istanbul University Journal of Sport Sciences 2003; 123-126. 